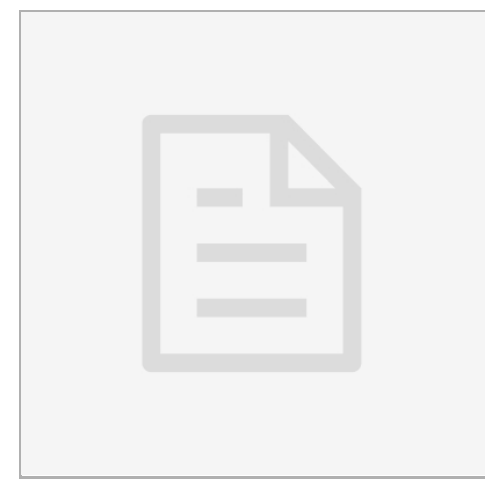

OCT 15, 2019

\section{open 2 ACCESs}

\section{DOI:}

dx.doi.org/10.17504/protocol s.io.7zrhp56

\section{Protocol Citation: Dana} Mozaffari, Laura

Kvedarauskaite 2019. 2-step Polymerase Chain Reaction (PCR). protocols.io

https://dx.doi.org/10.17504/p rotocols.io.7zrhp56

License: This is an open access protocol distributed under the terms of the Creative Commons Attribution License, which permits unrestricted use, distribution, and reproduction in any medium, provided the original author and source are credited

Protocol status: Working We use this protocol and it's working

Created: Oct 07, 2019

Last Modified: Oct 15, 2019

PROTOCOL integer ID: 28433

\title{
(3) 2-step Polymerase Chain Reaction (PCR)
}

Dana

Mozaffari ${ }^{1}$, ${ }^{1}$ EPFL - EPF Lausanne

\section{iGEM EPFL}

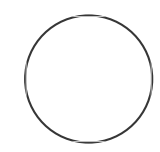

Dana Mozaffari

\section{ABSTRACT}

Polymerase Chain Reaction (PCR) is a method of making multiple copies of a DNA sequence, involving repeated reactions with a polymerase enzyme, which comes in different types, such as Taq-polymerase, Phusion or Q5.

To run a PCR reaction, one needs a DNA template to be amplified, one set of forward and reverse primers, a polymerase enzyme as well as various buffers.

This protocol describes the procedure to perform a two-step PCR reaction, in which the primers contain an extra non-binding overlap sequence which allows the assembly of a new sequence from a specific region of the template DNA.

This is done by using two sets of primers, one which adds a non-binding overlap sequence and one other set which add a desired sequence binding to the overlap region introduced by the first set of primers. 


\section{MATERIALS}

Reaction mixture for Gene specific reaction for $\mathbf{5 0} \boldsymbol{\mu l}$ :

- $0.5 \mu \mathrm{L}$ forward primer

- $0.5 \mu \mathrm{L}$ reverse primer

- $1.25 \mu \mathrm{L}$ template primer

- $20.25 \mu \mathrm{L} \mathrm{sdH} 20$

- $2.5 \mu \mathrm{L}$ DMSO

- $25 \mu \mathrm{L}$ Phusion polymerase Master Mix

Reaction mixture for extension PCR for $2 \times \mathbf{5 0} \boldsymbol{\mu l}$ :

- $1.0 \mu \mathrm{L}$ forward primer

- $1.0 \mu \mathrm{L}$ reverse primer

- $1.0 \mu \mathrm{L}$ template primer

- $42 \mu \mathrm{L} \mathrm{dH} 20$

- $5.0 \mu \mathrm{L}$ DMSO

- $50 \mu \mathrm{L}$ Phusion polymerase Master Mix

\section{Primers to add for final PCR}

- $0.5 \mu \mathrm{L}$ forward primer

- $0.5 \mu \mathrm{L}$ reverse primer

\section{Gene specific PCR}

1 Set up the thermocycler program

For initial denaturation

- $98^{\circ} \mathrm{C}$ for 2 minutes

For 35 cycles:

- $98^{\circ} \mathrm{C}$ for 30 seconds for denaturation

- 30 seconds for primers annealing at temperature depending on primers and polymerase

- $72^{\circ} \mathrm{C}$ for 30 seconds per kb of DNA for elongation

Final extension:

- $72^{\circ} \mathrm{C}$ for 7 minutes

- $4^{\circ} \mathrm{C}$ on hold

2 Prepare the master mix using the quantities specified in Materials 
3 Load the PCR mixture in thermocycler and start program.

4 Control the PCR by doing an agarose gel electrophoresis (follow Gel Electrophoresis Protocol)

\section{Extension PCR}

5 Set up the thermocycler program

For initial denaturation

- $98^{\circ} \mathrm{C}$ for 30 seconds

For 10 cycles:

- $98^{\circ} \mathrm{C}$ for 8 seconds for denaturation

- 20 seconds for primers annealing at temperature depending on primers and polymerase

- $72^{\circ} \mathrm{C}$ for 30 seconds per kb of DNA for elongation

Final extension:

- $72^{\circ} \mathrm{C}$ for 7 minutes

- $4^{\circ} \mathrm{C}$ on hold

6 Prepare the master mix with the gene specific PCR product and using the quantities specified in Materials

7 Load the reaction mixture in the thermocycler and start the program

\section{Final PCR}

8 Set up the thermocycler program 
For initial denaturation

- $98^{\circ} \mathrm{C}$ for 2 minutes

For 35 cycles:

- $98^{\circ} \mathrm{C}$ for 30 seconds for denaturation

- 30 seconds for primers annealing at temperature depending on primers and polymerase

- $72^{\circ} \mathrm{C}$ for 30 seconds per kb of DNA for elongation

Final extension:

- $72^{\circ} \mathrm{C}$ for 7 minutes

- $4^{\circ} \mathrm{C}$ on hold

9 When the extension PCR is done, directly add in the tubes the primers for the final PCR with the quantities specified in Materials.

Minimize the waiting time before starting the second reaction to keep polymerase activity high

10 Control the PCR by doing an agarose gel electrophoresis (follow Gel Electrophoresis Protocol)

11 Purifiy the PCR product with a DNA purification kit 